\title{
Market Withdrawal
}

National Cancer Institute

\section{Source}

National Cancer Institute. Market Withdrawal. NCI Thesaurus. Code C54699.

A removal or correction by manufacturer or owner of a marketed product that the FDA considers to be either no violation or in minor violation of the laws it administers, and against which the agency would not initiate legal action. The concept does not refer to redemption or liquidation of stocks issued by the company. 